\title{
Historical and current distribution, population size and possible migration routes of the Blue Swallow Hirundo atrocaerulea in Africa
}

\author{
STEVEN W. EVANS and H. BOUWMAN
}

\section{Summary}

The Blue Swallow Hirundo atrocaerulea is restricted to sub-Saharan Africa, its population size previously estimated at fewer than 1,500 pairs, and is classified as Vulnerable. A better understanding of its current distributional range, population size, protection status and migration routes would improve our ability to conserve the species and the grassland and wetland habitat on which it depends. We now estimate that the Blue Swallow population in the 1850 s may have numbered between 1,560 and 2,300 pairs. Based on an assessment of available data, we now estimate the total current Blue Swallow population at 1,006 pairs or 2,012 individuals, an estimated $36-56 \%$ decline over the last 150 years. There may be three separate Blue Swallow sub-populations and seven separate migratory routes between their breeding and non-breeding grounds. The Blue Swallow's range in South Africa and Swaziland has contracted by $74 \%$. The majority of Blue Swallows occupy unprotected areas on their non-breeding grounds in the Democratic Republic of the Congo, Uganda and Kenya. The Blue Swallow population in Africa will continue to decline unless the causes of reduction in Blue Swallow habitat quantity and quality can be stopped and sufficient and additional habitat set aside to sustain viable Blue Swallow populations throughout their range.

\section{Introduction}

The Blue Swallow Hirundo atrocaerulea is restricted to sub-Saharan Africa, migrating between its breeding grounds in south-eastern and north-eastern South Africa, north-western Swaziland, eastern Zimbabwe, western Mozambique, southern and northern Malawi, north-eastern Zambia, southern Tanzania and the south-eastern Democratic Republic of the Congo (DRC) and nonbreeding grounds in western Kenya, southern Uganda, north-western Tanzania and northeastern DRC (Turner and Rose 1989, Keith et al. 1992). The birds occupy their breeding grounds from late-September to mid-April and their non-breeding grounds from late-April to late August or early-September (Keith et al. 1992). The basic biology of the Blue Swallow is summarised in Keith et al. (1992) and Hockey et al. (2007).

The global Blue Swallow population, estimated at fewer than 1,500 pairs, is classified as 'Vulnerable' due to its small and rapidly declining population, resulting from the rapid reduction in the quantity and quality of its grassland and wetland habitat (BirdLife International 2000, 2008). The East African Blue Swallow population (Uganda, Kenya and Tanzania) is classified as 'Endangered' under East Africa regional Red Data criteria (Bennun and Njoroge 1996). The South African and Swaziland populations are both classified as 'Critically Endangered' (Evans and Barnes 2000, Monadjem et al. 2003).

Current maps of the African distribution range of the Blue Swallow are only approximate (e.g. Turner and Rose 1989). No quantitative assessment has previously been made of the decline in 
the Blue Swallow's distribution range and population size. Similarly, no assessment has been made of what portion of the Blue Swallow population is located in formally, partially, or unprotected areas on both their breeding and non-breeding grounds. Also, no attempt has been made to determine the migratory routes between their breeding and non-breeding grounds. A better understanding of the current distribution range, migratory routes, population size and protection status would improve our ability to conserve the Blue Swallow and the grassland and wetland habitat on which it and other biodiversity depends.

\section{Materials and methods}

\section{Distribution}

All literature and other available information on the Blue Swallow have been collected over the 12 years of the present study. In addition, copies of all nest record cards of Blue Swallows were obtained from BirdLife South Africa, the Avian Demography Unit, and BirdLife Zimbabwe. The Endangered Wildlife Trust's Blue Swallow Monitoring Database was also updated. Blue Swallow distribution data for South Africa and Zimbabwe, as contained in Allan and Earlé (1997), was obtained from the Avian Demography Unit as ArcView 3.2 shapefiles. The Zimbabwe Department of National Parks and Wildlife Management provided all the information on Blue Swallows contained in their Field Cards. In 2005, a request to all birders to submit their sightings and any additional information they may have collected on Blue Swallows was posted on the Southern African Bird Net. All references used are provided in Appendix 1 in Supplementary Materials.

All of the above information was carefully scrutinised and the following data extracted per country: locality, number of nests recorded, number of skins collected, number of birds sighted, the reference, and any additional notes. Only original data were included. In keeping with Harrison et al. 1997, locality data were used to determine in which quarter degree grid squares $\left(15^{\prime} \times 15^{\prime}\right)($ QDGS) Blue Swallows have been recorded. This was used in conjunction with ArcView 3.2 to compile Figures 1-7.

\section{Migratory routes}

The possible migratory routes used by Blue Swallows were largely determined by looking at the Blue Swallow breeding and non-breeding distribution ranges as they were in 1850 and classifying birds to be on passage to their non-breeding or breeding grounds if recorded outside of these areas in March-April and August-October, respectively. Information on the migratory patterns of other species was used (Berthold 1993) to compile a likely migratory scenario for the Blue Swallow.

\section{Population decline}

The South African and Swaziland distribution of the Blue Swallow based on QDGSs as it may have been in 1850 was compared with a map of the QDGSs known to contain breeding Blue Swallows in 2005. The reduction in QDGSs occupied by Blue Swallows over the past 155 years (1850-2005), and the current estimated population in South Africa and Swaziland, were used to estimate the 1850 population size for South Africa and Swaziland.

Literature was assembled on estimates of Blue Swallow populations from throughout its breeding and non-breeding range, and collated into a table. Estimates of Blue Swallow habitat surface area and the number of birds they contained were used to extrapolate the sub-population size for other population fragments. This was done for areas where they are known to occur and where there was some knowledge of suitable habitat, availability and extent. In this manner, an estimate of the entire Blue Swallow population was made per site occupied, and per country. This 
was used to assess the number of Blue Swallows that are protected (formally protected areas), partially protected (Ramsar Sites, Natural Heritage Sites, Forest Reserves, Important Bird Areas that are not formally protected areas), and unprotected, on both their breeding and non-breeding grounds.

\section{Results}

\section{Distribution and area}

Throughout their entire and exclusively African distribution range, Blue Swallows have been recorded between $26.11^{\circ}$ to $36.95^{\circ} \mathrm{E}$ and $2.40^{\circ} \mathrm{N}$ to $30.60^{\circ} \mathrm{S}$ (Figure 1 ). On their non-breeding range, the Blue Swallows may have occupied as many as 23 QDGSs in the 1850 , with a combined surface area of approximately $16,100 \mathrm{~km}^{2}$ (Figures $1-2$ ). On their breeding grounds, the Blue Swallows may have occupied as many as 138 QDGSs, in the 1850 , with a combined surface area of approximately $96,600 \mathrm{~km}^{2}$ (Figures 1 and $3-5$ ). As each QDGS is about $700 \mathrm{~km}^{2}$ in size and

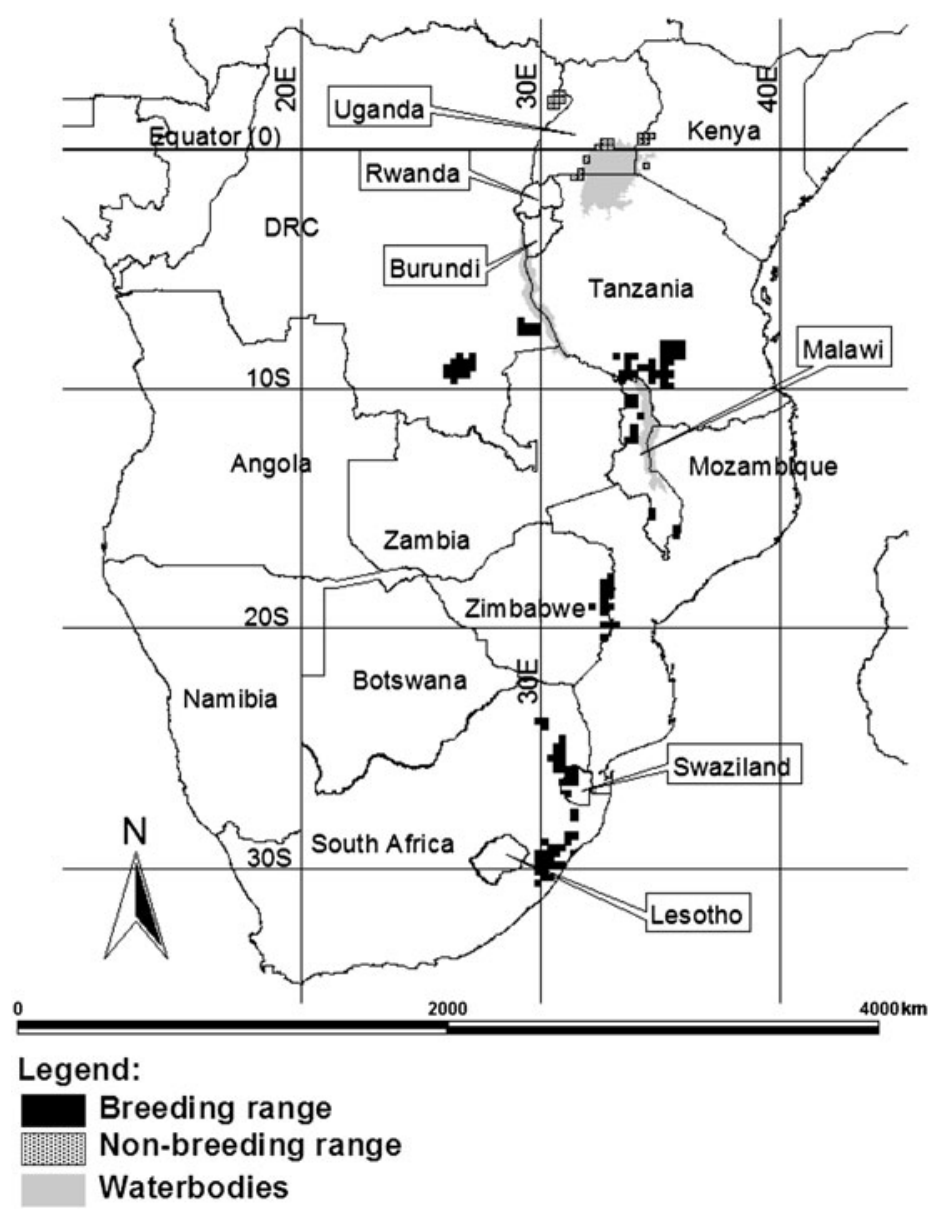

Figure 1. The Blue Swallow African distribution range per quarter degree grid square based on distribution records 1850-2005. See the supplementary material for the references used to compile this map. 


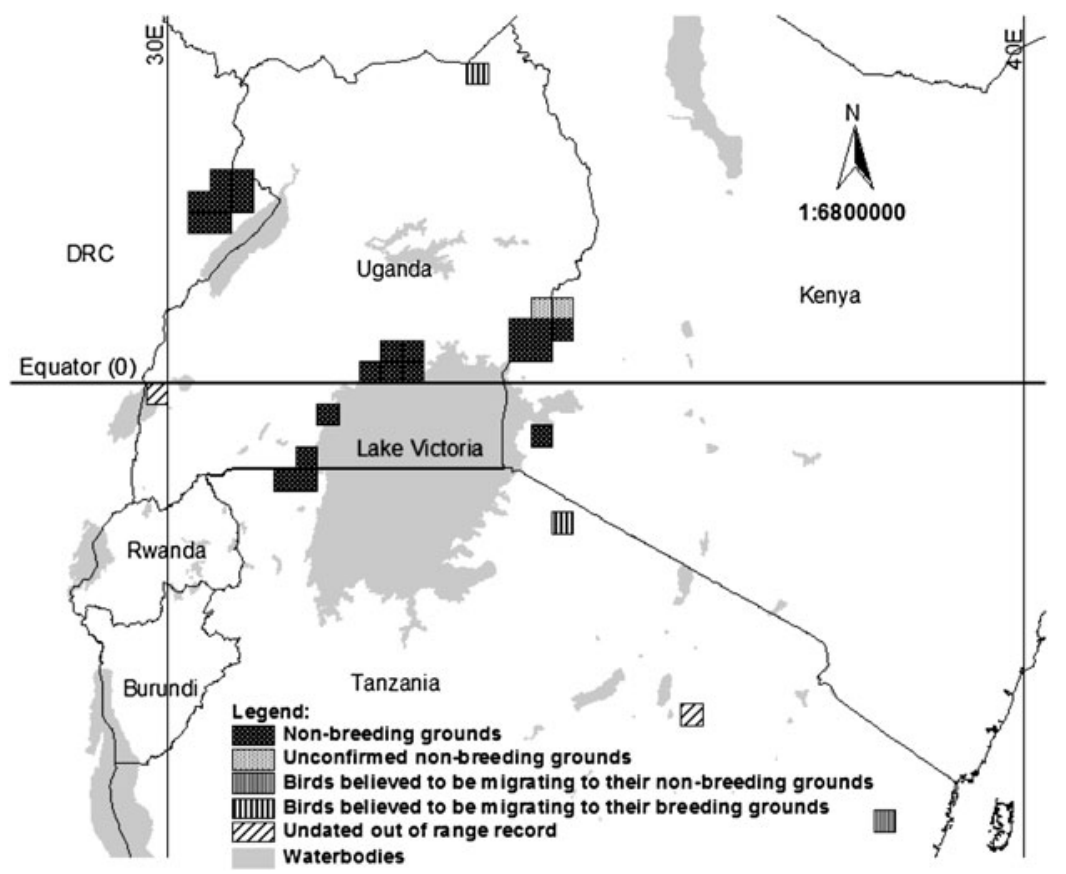

Figure 2. Blue Swallow distribution in the north-eastern DRC, Uganda, Kenya and northern Tanzania per quarter degree grid square based on distribution records 1850-2005. See Appendix 1 for the references used to compile this map.

Blue Swallows were probably not distributed throughout each QDGS, the above figures are probably an over-estimation of the 1850 range. However, based on this estimation, the original Blue Swallow breeding range was approximately $83 \%$ larger than their non-breeding range.

\section{Migratory routes}

Of the available records of Blue Swallows outside their usual breeding and non-breeding distribution ranges, it was judged that nine records were insufficiently or inaccurately dated for use in this analysis (Table 1 ). Based on the observation dates, six of the II accepted records of Blue Swallows outside their usual breeding and non-breeding ranges were of birds that may be on passage to their non-breeding grounds; the other five were probably birds on route to their breeding grounds, holding some clue as to the migratory routes used by Blue Swallows. Seven of these records are of single birds, while the others (two from Zimbabwe and one each from Malawi and Zambia) are of groups of birds. (Table 1 , Figures 3 and 6).

Figure 6 illustrates possible migratory routes that Blue Swallows may use, indicating three separate Blue Swallow sub-populations. There appears to be a disjuncture in the distribution of Blue Swallows between south-western and south-eastern Uganda. Some birds from the breeding grounds may migrate around the western side of Lake Victoria and others around the eastern. We therefore considered Lakes Victoria and Albert/Edward as barriers separating eastern and western migration routes and therefore sub-populations, and these sub-populations to fly east and west of Lakes Tanganyika and Malawi on migration. The first sub-population breeds in the south-eastern DRC and migrates (Route I) to the north-eastern DRC (Lendu Plateau). The second subpopulation breeds in South Africa, Zimbabwe, Mozambique, northern and south-western Malawi 


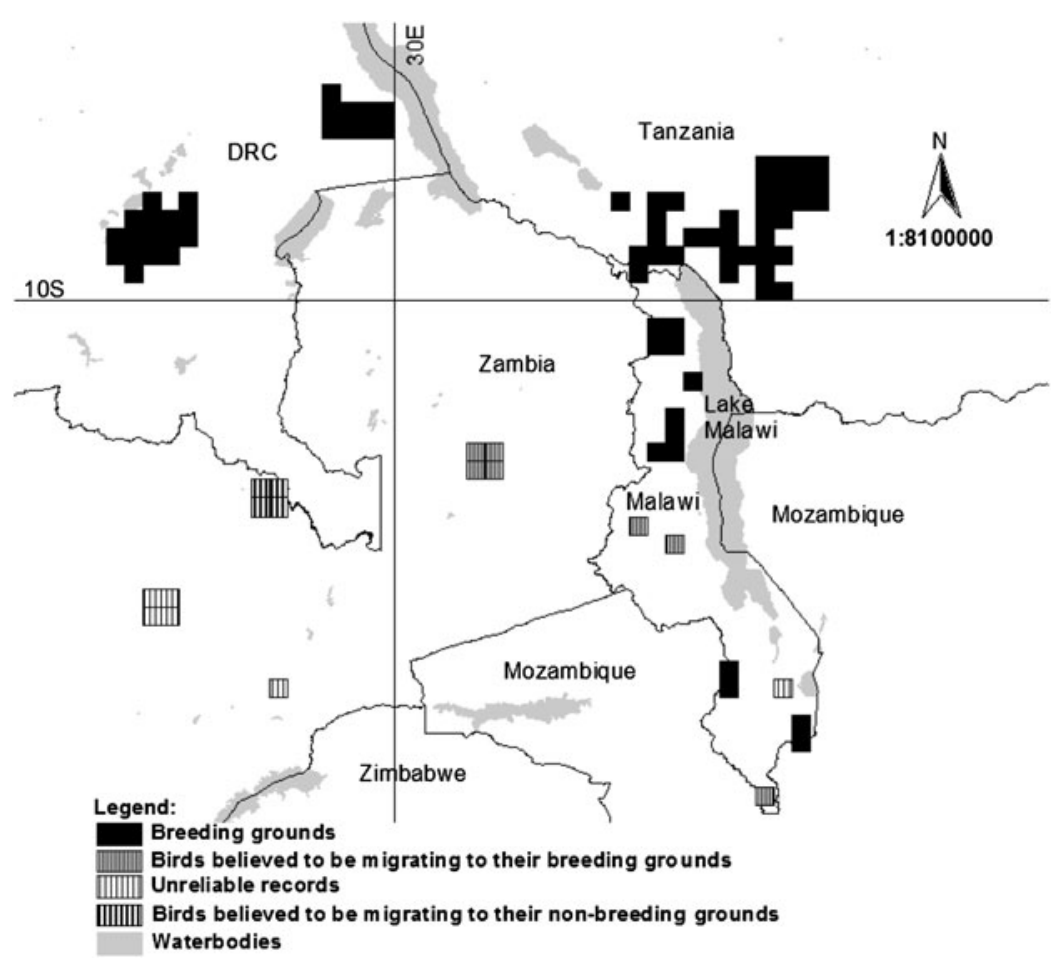

Figure 3. Blue Swallow distribution in south-eastern DRC, southern Tanzania, Malawi, adjacent Mozambique and Zambia per quarter degree grid square based on distribution records 1850-2005. See the supplementary material for the references used to compile this map.

(Misuku Hills, Nyika National Park, North and South Viphya and Kirk Range), and south-western Tanzania (Umalali Mountains, Kitulo Plateau and Mount Rungwe) and migrates (Routes 2-5) to western Uganda and north-western Tanzania. The third breeds in south-eastern Malawi (Mount Mulanje) and southern Tanzania (Livingston Mountains and Udzungwa Mountains) and migrates (Routes 6 and 7) to Kenya and eastern Uganda. Except for the larger lakes, there appear to be no major mountain ranges or deserts that would act as barriers on the proposed routes.

Blue Swallows might migrate in groups. Just prior to migration, at the Blue Swallow Natural Heritage Site (South Africa), it has been observed towards the end of three Blue Swallow breeding seasons that Blue Swallows gather in groups (of up to 13) and then disappear, suggesting group migration (S. W. Evans pers. obs).

\section{Population size and threat status}

Since 1850 and before commercial forestry, Blue Swallows were documented occupying 49 QDGSs in South Africa and Swaziland (Allan et al. 1997). They were also recorded outside their normal breeding distribution range in a further seven QDGSs in South Africa. Based on historic (1850) and current (2005) distribution, the Blue Swallow's range has declined by $74 \%$, from 49 QDGSs to 13 (Figures 5 and 7). During this period in South Africa alone, there was a reduction from 41 QDGSs to 12, a 71\% decline (Figures 5 and 6). During this period in Swaziland, the distribution range declined from eight QDGSs to one or possibly two, a $75-88 \%$ decline (Figures 5 and 7 ). 


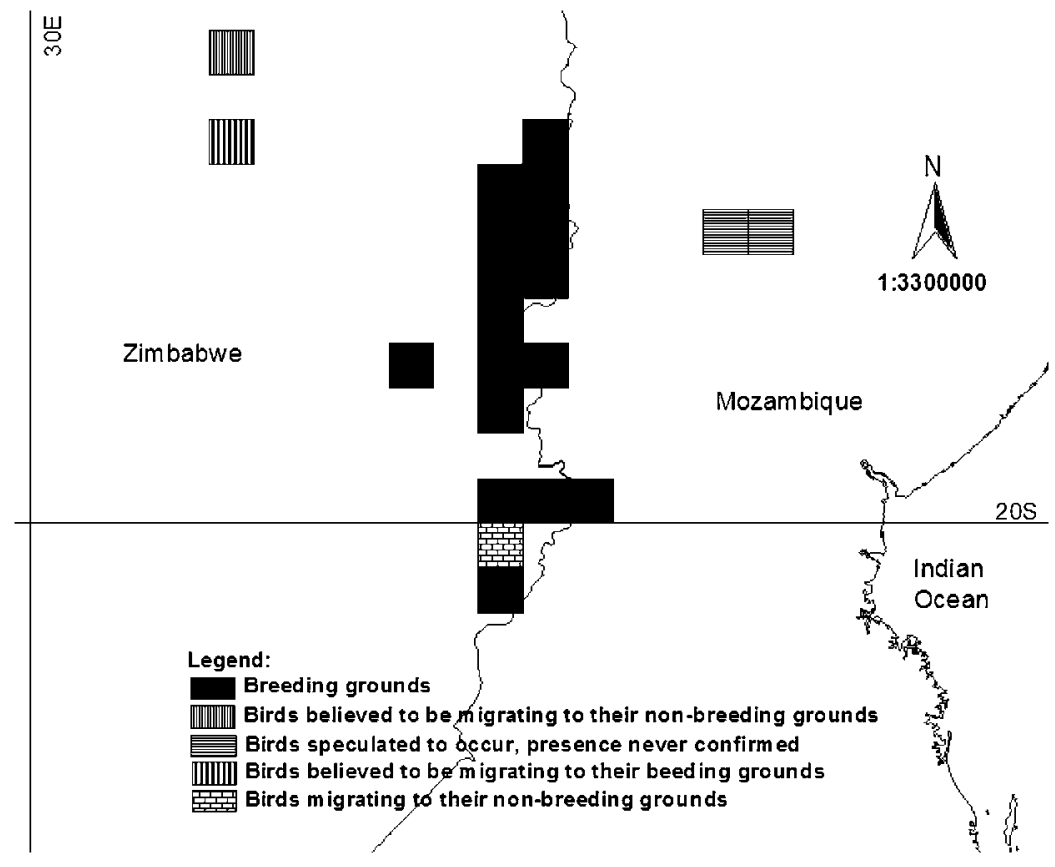

Figure 4. Blue Swallow distribution in Zimbabwe per quarter degree grid square based on distribution records 1850-2005. See the supplementary material for the references used to compile this map.

Assuming that the densities of Blue Swallows on their breeding grounds are similar to Malawi and Zimbabwe, the Blue Swallow population in the 1850 os may have numbered 1,960-2,700 pairs (Table 2). Based on these estimations, the total current Blue Swallow population is calculated at approximately 1,006 pairs or 2,012 individual birds, a $36-56 \%$ decline from 1850 to 2005 , compared with a decline of $74 \%$ for South Africa and Swaziland.

As the Blue Swallow is a facultative co-operative breeder (Tree 1989, Du Plessis et al. 1995, Wakelin 2006), the 2,012 individual birds estimated for the current Blue Swallow population, based on active nest densities, may be an underestimation of the actual number of Blue Swallows, but not of active nests, as there may be more than two birds present at each active nest (Wakelin 2006). Many Blue Swallows pairs are believed to breed co-operatively in KwaZuluNatal with a mean of two females and one male per nest (Wakelin 2006). At the study site in Mpumalanga containing nine pairs between 1995 and 1998, there was an equal sex ratio; cooperative breeding may have been taking place at only one nest (S. Evans unpubl. data).

Information on the longevity of swallows and martins that have northern and/or southern temperate and/or tropical zone breeding migrant populations that migrate into the range of their tropical breeding resident conspecifics (Banded Martin Riparia cincta, Lesser Striped-swallow Cecrops abyssinica, Red-breasted Swallow Cecrops semirufa and White-throated Swallow Hirundo albigularis) indicates that breeding longevity is approximately $1-7$ years (McClure 1974, Rydzewski 1978, Irwin 1981, Earlé 1987, Turner and Rose 1989). The same was found for tropical breeding resident swallows and martins (Brown-throated Martin Riparia paludicola, Pacific Swallow Hirundo tahitica, and Ethiopian Swallow Hirundo aethiopica) (McClure 1974, Rydzewski 1978, Irwin 1981, Earlé 1987, Turner and Rose 1989). A conservative estimate of Blue Swallow longevity was therefore taken to be six years, and three generations was taken to span 18 years. 


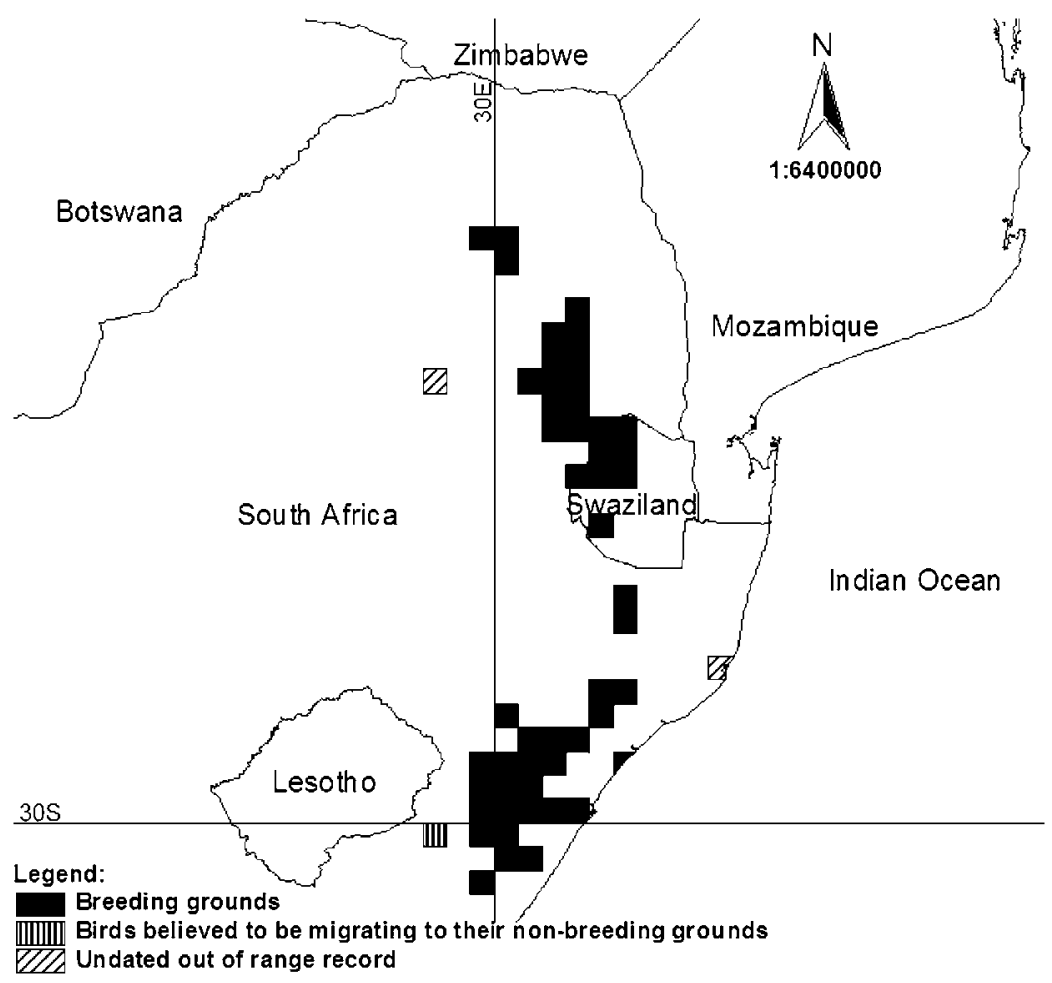

Figure 5. Blue Swallow distribution per quarter degree grid squares in South Africa and Swaziland based on all distribution records 1850-2005. See the supplementary material for the references used to compile this map.

A decline in the Blue Swallow population in South Africa and Swaziland of $74 \%$ in 155 years represents a mean decline of $0.48 \%$ per year from 1850 to 2005 . However, as commercial forestry commenced in Blue Swallow areas in the late 188 os (van der Zel 1988) a 74\% decline in 115 years (1890-2005) equates to a decline of $0.64 \%$ per year (Figures 5 and 7 ). A decline of $56 \%$ in the total Blue Swallow population over 155 years represents a mean decline of $0.36 \%$ per year from 1850 to 2005 . Taking a cautious approach and therefore the worst-case scenario, the Blue Swallow qualifies as 'Vulnerable' under IUCN criterion $C_{I}$ as the Blue Swallow population is estimated to have declined by as much as $12 \%$ over the next three generations. In addition, the Blue Swallow qualifies as Vulnerable under IUCN criterion C2a(i) due to a continuing decline projected in the number of mature individuals and no Blue Swallow sub-population estimated to contain more than 1 ,ooo mature individuals IUCN/SSC (2000).

\section{Protection status}

Throughout their breeding range, approximately $60 \%$ of the Blue Swallow population is in strictly protected areas, a further $23 \%$ in partially protected areas (forest reserves, natural heritage sites and Ramsar sites), and an estimated $17 \%$ is unprotected (Table 3 ). The situation is unfortunately very different for the Blue Swallows when on their non-breeding range where only an estimated $28 \%$ of the population is in formally protected areas, an estimated $25 \%$ in partially protected areas, and an estimated $47 \%$ are unprotected (Table 3 ). 
Table 1. Summary of the information available of all records of Blue Swallows considered out of range or on passage.

\begin{tabular}{|c|c|c|c|c|}
\hline Country & No. of birds & Date & Locality & Source \\
\hline \multicolumn{5}{|c|}{ Potentially on migration to the non-breeding grounds: } \\
\hline Zimbabwe $^{4}$ & 1 bird & $12 / 04 / 1951$ & Glendale Farm & Arkell and Brooke 1967 \\
\hline Malawi $^{4}$ & birds & $27-29 / 03 / 1958$ & Nsanje & Long 1959 \\
\hline Malawi ${ }^{4}$ & singles & $02 / 03 / 1994$ & Kasungu & Dowsett-Lemaire $2006 \mathrm{~b}$ \\
\hline Malawi $^{4}$ & singles & $11 / 04 / 1992$ & Ntchisi Mountain & Dowsett-Lemaire $2006 \mathrm{~b}$ \\
\hline Tanzania $^{4}$ & 1 bird & $? ? / 04 /<1980$ & Korogwe & Brown and Britton 1980 \\
\hline Zimbabwe $^{4}$ & birds & $? ? / 0_{3} /<1981$ & Chipinga Uplands & Irwin 1981 \\
\hline \multicolumn{5}{|c|}{ Potentially on migration to the breeding grounds } \\
\hline Malawi $^{1}$ & I bird (skin) & $23 / 10 / 1908$ & Zomba Plateau & Dowsett 1981 \\
\hline South Africa ${ }^{2}$ & I bird & 19/o9/1957 & Swartberg District (KZN) & Shepard 1962 \\
\hline Zimbabwe $^{4}$ & I bird & $15 / 09 / 1960$ & Borrowdale Farm & Brooke 1962,1963 \\
\hline Zambia $^{2}$ & 1 bird & $12 / 09 / 1971$ & Kabulonga Dam, Lusaka & Tucker 1971 \\
\hline Zimbabwe $^{4}$ & birds & ??/o9/<1981 & Chipinga Uplands & Irwin 1981 \\
\hline Tanzania $^{4}$ & I bird & 12/08/1994 & Serengeti Nat. Park & Zimmerman et al. 1996 \\
\hline Uganda $^{4}$ & I female & ??/og/1997 & Kidepo Valley Nat. Park & Butchard 1996 \\
\hline Zambia $^{4}$ & 6 birds & 05/og/???? & Mutinondo Wilderness & Dowsett et al. 2008 \\
\hline \multicolumn{5}{|l|}{ Vagrants } \\
\hline Zambia & I bird & 07/01/1995 & Kitwe & Leonard 1995 \\
\hline Zambia $^{2}$ & I bird & 21/01/2006 & Kafue River (near Chunga) & Dowsett et al. 2008 \\
\hline Malawi $^{2}$ & several & ??/о1/1976 & Zomba Mountain & $\begin{array}{l}\text { Dowsett-Lemaire \& } \\
\text { Dowsett } 2006\end{array}$ \\
\hline \multicolumn{5}{|l|}{ Unknown: } \\
\hline Tanzania & 1 bird & $?$ & Tarangira National Park & Baker, pers. comm. 2007 \\
\hline South Africa ${ }^{3}$ & I bird & $20 / 13 / 1954$ & Gonubie Bird Sanctuary & $\begin{array}{l}\text { Courtney-Latimer } \\
\text { 1962, 1964 }\end{array}$ \\
\hline South Africa ${ }^{3}$ & 1 bird & 21/13/1955 & Gonubie Bird Sanctuary & $\begin{array}{l}\text { Courtney-Latimer } \\
\text { 1962, 1964 }\end{array}$ \\
\hline South Africa & 1 bird & $<1958$ & near Tsitsikama & Skead 1967 \\
\hline South Africa & 1 bird & $<1960$ & Loskop Dam & Prozesky 1960 \\
\hline South Africa & I bird & $<1980$ & Eastern Shores L. St. Lucia & Berruti 1980 \\
\hline Mozambique & I bird & $<1980$ & Zambezi River Mouth & Brown and Britton 1980 \\
\hline South Africa ${ }^{2}$ & I bird & $<1981$ & Stellenbosch & Anon 1981 \\
\hline Uganda & birds & $<1995$ & Queen E. Nat. Park & Wilson 1995 \\
\hline
\end{tabular}

${ }^{1}$ The locality reported for this skin should be accepted with reservation

${ }^{2}$ Unconfirmed and not used further

${ }^{3}$ The month was incorrectly documented as " 13 ", may be either the first or third month of the year?

${ }^{4}$ II records of birds possibly on migration and used in the analyses.

\section{Discussion}

\section{Population decline}

The Blue Swallow population decline (Figures 5 and 7 ) in South Africa and Swaziland has primarily been due to a decrease in the grassland and wetland habitat quantity and quality available (Parker 1994, Allan et al. 1997, Evans and Barnes 2000, Monadjem et al. 2006). A reduction in habitat quantity and quality on the non-breeding grounds would also support a smaller population and result in there being fewer birds returning to South Africa and Swaziland to breed and therefore a decline in the overall Blue Swallow population (Evans et al. 2002).

The Blue Swallow population in Africa will continue to decline unless sufficient habitat is set aside to sustain viable populations. The International Blue Swallow Action Plan compiled in 2002 


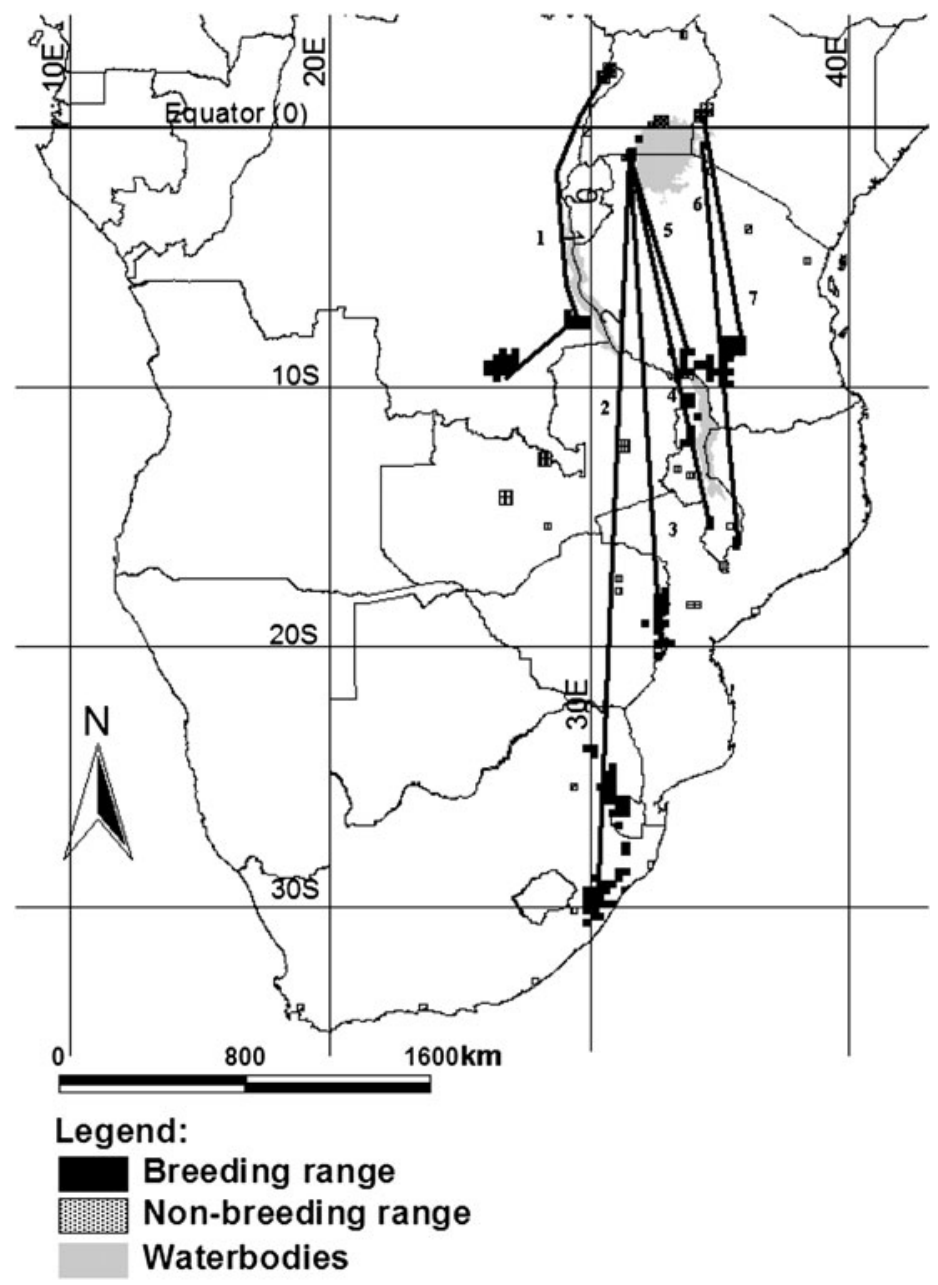

Figure 6. Seven possible migratory routes used by Blue Swallows between their breeding and non-breeding grounds (also see Table 1 ).

by representatives from nine of the ten Blue Swallow range states (Evans et al. 2002) needs to be reviewed, updated and implemented.

\section{Important countries for conserving the Blue Swallow}

The most important countries for conserving breeding populations of the Blue Swallow and its unique grassland and wetland habitats are Zimbabwe, Malawi and southern Tanzania, as combined they contain the largest numbers of breeding birds within the least fragmented habitat and contain $74 \%$ of the current estimated total breeding population (Tables 2 and 3 ). No dedicated survey of the Blue Swallow has been done in southern Tanzania and this is urgently needed.

When Blue Swallows are on their non-breeding range, Uganda and Kenya are the most important countries for conserving the birds and their wetland habitats, as these two countries currently contain an estimated $73 \%$ of the combined non-breeding Blue Swallow population. 


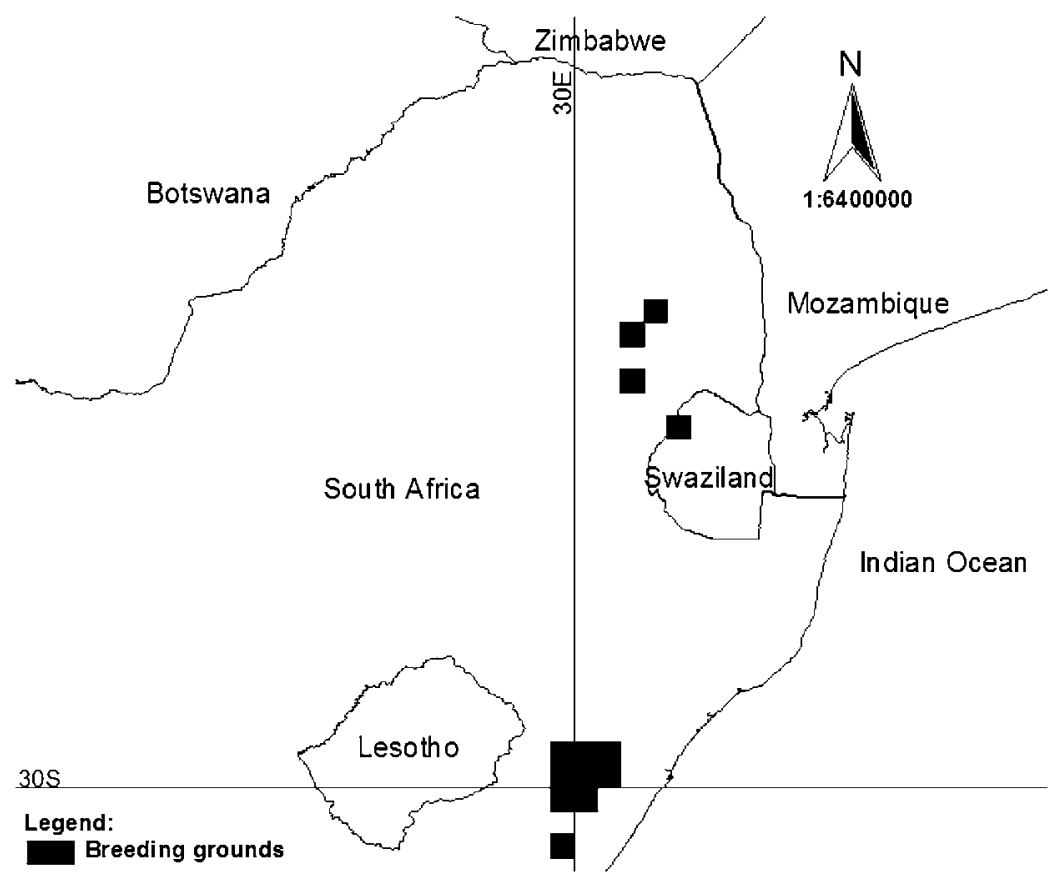

Figure 7. The 13 quarter degree grid squares in which Blue Swallows were breeding in 2005 (Monadjem et al. 2006).

\section{Blue Swallow sub-populations}

The Blue Swallow may be distributed within three separate sub-populations (Figure 6); it is therefore necessary to conserve the Blue Swallow on breeding and non-breeding grounds within all three separate sub-populations in order to conserve current genetic diversity. Blue Swallow stopover sites need to be identified along their migratory routes and programmes initiated to conserve them. Unfortunately, the impacts of changes along the Blue Swallow migratory routes are unknown and their effects on the population can not yet be determined. Studies are urgently needed to confirm the migratory routes used by Blue Swallows.

\section{Protection status}

Loss of habitat quality and quantity for Blue Swallows may be expected to be greatest in unprotected and partially protected areas, with very little to no habitat loss in formally protected areas. This would suggest that the current Blue Swallow population is at greatest risk on their non-breeding grounds where $47 \%$ of the population occurs in unprotected areas in Uganda and the Lendu Plateau in the north-eastern DRC.

Although this assessment was based on estimated numbers and distribution on their breeding and non-breeding range, it does provide a good indication that conservation of the Blue Swallow in Uganda and the Lendu Plateau in the DRC is important for securing its future survival.

\section{Habitat on migratory routes}

Six of the routes believed to be used by Blue Swallows are direct (Figure 6). It is believed that Blue Swallows follow Lake Tanganyika and the Albertine Rift as the leading lines aiding navigation 
Table 2. Estimate of the current total number of Blue Swallows ${ }^{\text {a }}$.

\begin{tabular}{lccl}
\hline Country & No. of pairs & No. of individuals & Survey or estimate \\
\hline Breeding Range $(\boldsymbol{n}=8)$ & & & \\
South Africa & 84 & 168 & Survey \\
Swaziland & 22 & $\sim 44$ & Estimate \\
Zimbabwe & $\sim 280$ & $\sim 560$ & Survey \\
Mozambique & $\sim 50$ & $\sim 100$ & Estimate \\
Malawi & $\sim 300$ & $\sim 600$ & Estimate \\
Zambia & 10 & 20 & Survey \\
S Tanzania & $\sim 160$ & $\sim 320$ & Estimate \\
SE DRC & $\sim 100$ & $\sim 200$ & Estimate \\
Total & $\sim 1,006$ & 2,012 & \\
Non-Breeding Range $(n=4)$ & & \\
NW Tanzania & & $\sim 346$ & Estimate \\
Kenya & & $\sim 500$ & Survey \\
Uganda & & 966 & Survey \\
NE DRC & 200 & Estimate \\
Total & 2,012 & \\
\hline
\end{tabular}

a⿳Barnes 1998, Bennun and Njoroge 1999, 2001, Childes in litt. 1999, 2000, Baker and Baker 2001, Byaruhanga et al. 2001, Childes 2001, Demey and Louette 2001, Dowsett-Lemaire et al. 2001, Fishpool and Evans 2001, Leonard 2001, Parker 2001, Monadjem et al. 2003, Byaruhanga and Evans 2004, Stjernstedt 2004, EWT-Blue Swallow Working Group Monitoring records 2005.

between their breeding grounds in the south-eastern DRC and their non-breeding grounds on the Lendu Plateau. It was found, for instance, that migrants from North America migrating south either use the Rocky Mountains to their west or migrate south between the west coast and the Rocky Mountains to their east, as leading lines and aids to migration (Hynes 2007). A direct migratory route between breeding and non-breeding grounds need not be a straight line due to barriers such as mountain ranges and deserts that have to be crossed or avoided (Hynes 2007). The Purple Martin Progne subis breeds in open woodlands, farms and towns in North America, and migrates to similar habitat in South America during the non-breeding season (Turner and Rose 1989). They must cross tropical forests on migration as there is no continuous open woodland linking North and South America (Turner and Rose 1989). Aerial insectivores such as swallows and martins are able to forage on the wing and migrate by day, and when on migration, stop over near water, presumably with insects (Hynes 2007). This demonstrates that longdistance migrants such as the Purple Martin, and presumably the Blue Swallow, do not need habitats characteristic of their breeding or non-breeding habitat along the entire length of their migratory route. There are no major mountain ranges or deserts along the indicated routes (Figure 7). The II records of Blue Swallows outside their usual breeding and non-breeding distribution ranges were all within savannah habitat which is not typical of the grassland and wetland habitat characteristic of their breeding and non-breeding ranges (Figures $2-5$ and 7 ).

\section{Distribution}

Sibley and Monroe (1990) erroneously included Lesotho in the southern African breeding distribution range of the Blue Swallow. Simmons and Barnard (2005) modelled Blue Swallow distribution from the distribution map and data in Harrison et al. (1997). This model erroneously included south-western Mozambique, south-eastern Free State, the east of Eastern Cape Province and western Lesotho as part of the Blue Swallow distribution range. The distribution map in Stevenson and Fanshawe (2002) includes Rwanda and northern Burundi in its nonbreeding distribution range. In all three cases, there are no records supporting these distributions. 
Table 3. Current estimated Blue Swallow numbers and proportions that are protected throughout their breeding and non-breeding ranges ${ }^{\mathrm{a}}$.

\begin{tabular}{|c|c|c|c|c|c|c|}
\hline \multirow[t]{2}{*}{ Country } & \multicolumn{2}{|c|}{ Strictly Protected } & \multicolumn{2}{|c|}{ Partially Protected } & \multicolumn{2}{|l|}{ Unprotected } \\
\hline & No. pairs & $\%$ of total & No. pairs & $\%$ of total & No. of pairs & $\%$ of total \\
\hline \multicolumn{7}{|c|}{ Breeding ranges } \\
\hline South Africa & 12 & & 10 & & 62 & \\
\hline Swaziland & 8 & & o & & 14 & \\
\hline Zimbabwe & 245 & & 20 & & 15 & \\
\hline Mozambique & 30 & & o & & 20 & \\
\hline Malawi & 250 & & 40 & & 10 & \\
\hline Zambia & 10 & & o & & o & \\
\hline S Tanzania & o & & 160 & & $\mathrm{o}$ & \\
\hline SE DRC & 50 & & o & & 50 & \\
\hline Total & 605 & 60 & 230 & 23 & 171 & 17 \\
\hline \multirow[t]{2}{*}{ Country } & \multicolumn{2}{|c|}{ Strictly Protected } & \multicolumn{2}{|c|}{ Partially Protected } & \multicolumn{2}{|l|}{ Unprotected } \\
\hline & No. birds & $\%$ of total & No. birds & $\%$ of total & No. of birds & $\%$ of total \\
\hline \multicolumn{7}{|c|}{ Non-breeding ranges } \\
\hline NW Tanzania & $\mathrm{O}$ & & 346 & & o & \\
\hline NE DRC & 100 & & o & & 100 & \\
\hline Kenya & 473 & & & & & 27 \\
\hline Uganda & o & & 151 & & 815 & \\
\hline Total & 573 & 28 & 497 & 25 & 942 & 47 \\
\hline
\end{tabular}

a Barnes 1998, Bennun and Njoroge 1999, 2001, Childes, pers. comm. 1999, 2000, Baker and Baker 2001, Byaruhanga et al. 2001, Childes 2001, Demey and Louette 2001, Dowsett-Lemaire et al. 2001, Fishpool and Evans 2001, Leonard 2001, Parker 2001, Monadjem et al. 2003, Byaruhanga and Evans 2004, Stjernstedt 2004, EWT-Blue Swallow Working Group Monitoring records 2005.

\section{Conclusions}

Numbers of Blue Swallows have declined by $56 \%$ over the last 155 years and only about 1,00o pairs are optimistically estimated to remain. With the low numbers to start with, and fewer still remaining, the survival of this species is in the balance. The Blue Swallow has lost large parts of its breeding range in southern Africa. Remnant Blue Swallow populations in southern Africa remain precarious. The remaining populations in Zimbabwe and Malawi now constitute the best survival option, but more could be done to formalise and upgrade the protection status of these areas. The non-breeding areas also need their protection status upgrading. The possible migratory routes need confirmation, as does the identification of any threats along these routes.

\section{Supplementary Material}

The supplementary materials referred to in this article can be found at journals.cambridge. org $/$ bci

\section{Acknowledgements}

The Blue Swallow Working Group of the Endangered Wildlife Trust, North-West University, Paul Matiku, Achilles Byaruhanga, Warwick Tarboton, David Johnson, Peter Mundy, Bob Dowsett and Francois Dowsett-Lemaire are thanked for their contributions to this research. 


\section{References}

Allan, D. G. and Earlé, R. A. (1997) Blue Swallow Blouswael Hirundo atrocaerulea. Pp. 52-53 in J. A Harrison, D. G. Allan, L. G. Underhill, M. Herremans, A. J. Tree, V. Parker and C. J. Brown, eds. The atlas of Southern African birds. Vol. 2. Cape Town: CTP Book Printers Ltd.

Allan, D. G., Harrison, J. A., Navarro, R. A., Van Wilgen, B. W. and Thompson, M. W. (1997) The impact of commercial afforestation on bird populations in Mpumalanga - insights from bird-atlas data. Biol. Conserv. 79: 173-185.

Anon. (1981) A guide to the birds of the south western Cape. Cape Town: Cape Bird Club.

Arkell, R. G. and Brooke, R. K. (1967) Birds of Glendale, Rhodesia. S. Afr. Avi. Ser. 53: 1-23.

Baker, N. E and Baker, L. M. (2001) Tanzania. Pp. 897-945 in L. D. C. Fishpool and M. I. Evans, eds. Important Bird Areas of Africa and associated islands: Priority sites for conservation. Newbury and Cambridge, UK: Pisces Publications and BirdLife International (BirdLife Conservation Series no. 11).

Barnes, K. N., ed. (1998) The Important Bird Areas of southern Africa. Johannesburg: BirdLife South Africa.

Bennun, L. and Njoroge, P., eds. (1996) Birds to watch in East Africa: A preliminary Red Data list. National Museums of Kenya Research Reports of the Centre for Biodiversity: Ornithology 23.

Bennun, L. and Njoroge, P. (1999) Important Bird Areas in Kenya. Nairobi: Ornithology Department, National Museums of Kenya.

Bennun, L. and Njoroge, P. (2001) Kenya. Pp. 419-421, 444 and 456 in L. D. C. Fishpool and M. I. Evans, eds. Important bird areas of Africa and associated islands: Priority sites for conservation. Newbury and Cambridge, UK: Pisces Publications and BirdLife International (BirdLife Conservation Series no. 11).

Berruti, A. (1980) Birds of Lake St Lucia. Southern Birds 8: 56 .

Berthold, P. (1993) Bird migration: A general survey. Oxford: Oxford University Press.

BirdLife International (2000) Threatened birds of the world. Barcelona and Cam- bridge, UK: Lynx Edicions and Bird Life International.

BirdLife International (2008) Hirundo atrocaerulea. In: IUCN 2008. 2008 IUCN Red List of Threatened Species. <www.iucnredlist. org $>$. Downloaded on 18 February 2009.

Brown, L. H. and Britton, P. L. (1980) The breeding seasons of East African birds. Nairobi: East African Natural History Society.

Brooke, R. K. (1962) Bird and human mimics. Honeyguide 37: 2-3.

Brooke, R. K. (1963) Birds round Salisbury, then and now. S. Afr. Avi. Ser. 9: 1-7.

Butchard, D. (1996). Blue Swallow at Kidepo Valley National Park, northern Uganda. The Hornbill 46: 15.

Byaruhanga, A. and Evans, S. W. (2004) Blue Swallow distribution in Uganda. Poster Presentation. Pan African Ornithological Congress, Djerba, Tunisia.

Byaruhanga, A., Kasoma, P. and Pomeroy, D. (2001) Important bird areas in Uganda. Kampala: Nature Uganda.

Childes, S. L. (2001) Blue Swallow (Hirundo atrocaerulea) Status and distribution in Zimbabwe. Unpublished report. Harare: BirdLife Zimbabwe.

Courtenay-Latimer, M. (1962) Birds seen in the Gonubie bird sanctuary. Ostrich 33: 38-40.

Courtenay-Latimer, M. (1964) Checklist of the birds of the East London area. S. Afr. Avi. Series 20: 62.

Demey, R., and Louette, M. (2001) Democratic Republic of Congo. Pp. 199-218 in L. D. C. Fishpool and M. I. Evans, eds. Important bird areas of Africa and associated islands: Priority sites for conservation. Newbury and Cambridge, UK: Pisces Publications and BirdLife International (BirdLife Conservation Series no. II).

Dowsett-Lemaire, F., Dowsett, R. J. and Dyer, M. (2001) Malawi. Pp. 539-555 in L. D. C. Fishpool and M. I. Evans, eds. Important bird areas of Africa and associated islands: Priority sites for conservation. Newbury and Cambridge, UK: Pisces Publications and BirdLife International (BirdLife Conservation Series no. 11). 
Dowsett, R. J. (198I) The past and present distribution of montane birds in Malawi. Nyala 7: 25-45.

Dowsett, R. J., Aspinwall, D. R. and DowsettLemaire, F. (2008) The birds of Zambia. Liège: Tauraco Press \& Aves.

$\mathrm{Du}$ Plessis, M. A., Siegfried, W. R. and Armstrong, A. J. (1995) Ecological and lifehistory correlates of cooperative breeding in South African birds. Oecologia 102: 180-188.

Earlé, R. A. (1987) Ringing and recovery details of four southern African swallow species. Safring News 16: 67-72.

Endangered Wildlife Trust - Blue Swallow Working Group Monitoring Records. 2005. Unpublished. Johannesburg: Endangered Wildlife Trust.

Evans, S. W. and Barnes, K. N. (2000) Blue Swallow Hirundo atrocaerulea. Pp. 3234 in K. N. Barnes, ed. The Eskom Red Data Book of birds of South Africa, Lesotho and Swaziland. Johannesburg: BirdLife South Africa.

Evans, S. W., Cohen, L., Sande, E., Monadjem, A., Hoffmann, D., Mattison, H., Newbery, P., Ndanganga, K. and Friedmann, Y., eds. (2002) Blue Swallow (Hirundo atrocaerulea) international action plan. Final Workshop Report. Conservation Breeding Specialist Group South Africa. Endangered Wildlife Trust, South Africa.

Fishpool, L. D. C. and Evans, M. I., eds. (200I) Important bird areas in Africa and associated islands: Priority sites for conservation. Newbury and Cambridge, UK: Pisces Publications and BirdLife International (BirdLife Conservation Series no. II).

Harrison, J. A., Allan, D. G., Underhill, L. G., Herremans, M., Tree, A. J., Parker, V. and Brown, C. J., eds. (1997) The atlas of southern African birds Vol. 2. Cape Town: CTP Book Printers Ltd.

Hockey, P. A. R., Dean, W. R. J. and Ryan, P. G., eds. (2007) Roberts birds of southern Africa VIIth edition. Cape Town: Trustees of the John Voelcker Bird Book Fund. Hynes, S.. ed (2007) The atlas of bird migration. Tracing the great journeys of the world's birds. South Africa: Struik Publishers.

Irwin, M. P. S. (1981) The birds of Zimbabwe. Salisbury: Quest.
IUCN/SSC (200o) IUCN Red List categories. Gland, Switzerland: IUCN Species Survival Commission.

Keith, S., Urban, E. K. and Fry, C. H., eds. (1992) Birds of Africa. Vol. 4. London: Academic Press.

Leonard, P. M. (1995) A Blue Swallow near Kitwe. Zambia Orn. Soc. Newsl. 25: 3-4.

Leonard, P. M. (2001) Zambia. Pp. 1005-1024 in L. D. C. Fishpool and M. I Evans, eds. Important bird areas of Africa and associated islands: Priority sites for conservation. Newbury and Cambridge, UK: Pisces Publications and BirdLife International (BirdLife Conservation Series no. II).

Long, R. C. (1959) Recent interesting species in the Port Herald District, Nyasaland. Ostrich 30: 136-137.

McClure, H. E. (1974) Migration and survival of the birds of Asia. Bangkok: US Army Medical Component, SEATO Medical Project.

Monadjem, A., Boycott, R. C., Parker, V. and Culverwell, J. (2003) Threatened vertebrates of Swaziland. Swaziland Red Data Book: Fish, amphibians, reptiles, birds and mammals. Swaziland: Ministry of Tourism, Environment and Communications.

Monadjem, A., Boycott, R. C., Roques, K., Gama, R., and Garcelon, D. (2006) Breeding biology and conservation status of the Blue Swallow Hirundo atrocaerulea in Swaziland. Bird Conserv. Internatn. 16: 1-10.

Parker, V. (1994) Swaziland bird atlas. 19851991. Mbabane, Swaziland: Websters.

Parker, V. (2001) Mozambique. Pp. 627-638 in L. D. C. Fishpool and M. I Evans, eds. Important bird areas of Africa and associated islands: Priority sites for conservation. Newbury and Cambridge, UK: Pisces Publications and BirdLife International (BirdLife Conservation Series no. 11).

Prozesky, O. P. M. (1960) The birds of Loskop Dam. Fauna \& Flora 11: 63-74.

Rydzewski, W. (1978) The longevity of ringed birds. Ring 96-97: 218-262.

Shephard, J. B. (1962) Check list of birds of Swartberg district. S. Afr. Avif. Ser. 6: 12.

Sibley, C. G. and Monroe, B. L. Jr. (1990) Distribution and taxonomy of birds of the world. New Haven: Yale University. Press. 
Simmons, R. E. and Barnard, P. (2005) Too hot to handle? Africa Birds and Birding 10: 52-6o.

Skead, C. J. (1967) Ecology of birds in the Eastern Cape Province. Ostrich Suppl. 7: 1-103.

Stevenson, T. and Fanshawe, J. (2002) Field guide to the birds of East Africa. London: $\mathrm{T} \& \mathrm{AD}$ Poyser.

Stjernstedt, R. (2004) Preliminary survey of Blue Swallows on the Nyika Plateau, Zambia. Unpublished report. Lusaka, Zambia: Zambian Ornithological Society.

Tree, A. J. (1989) Recent reports. Honeyguide 35: 76-83.

Tucker, J. J. (1971) Blue Swallow near Lusaka. Bull. Zambian Orn. Soc. 3: 59.

Turner, A. and Rose, C. (1989) A handbook to the swallows and martins of the world. London: Christopher Helm. van der Zel, D. W. (1988) A forest map of southern Africa with the aid of LANDSAT imagery. Pretoria, South Africa: CSIR. (South African National Scientific Programmes Report no. 154).

Wakelin, J. (2006) An investigation to determine the critical habitat requirements of the breeding Blue Swallow Hirundo atrocaerulea Sundevall. Unpublished MSc thesis. Pietermaritzburg: University of KwaZulu-Natal.

Wilson, S. E. (1995) Birds and mammals checklists for ten national parks in Uganda. Kampala: Uganda National Parks.

Zimmerman, D. A., Turner, D. A. and Pearson, D. J. (1996) Birds of Kenya and northern Tanzania. Halfway House, South Africa: Russell Friedman Books CC.

\section{STEVEN W. EVANS*, H. BOUWMAN}

School of Environmental Sciences and Development (Zoology), North-West University, Private Bag X 6001, Potchefstroom 2520, South Africa

*Author for correspondence; e-mail: stevenwe@vodamail.co.za

Received 27 March 2009; revision accepted 7 September 2009; Published online 19 March 2010 